\title{
Implementasi Pilar-Pilar Karakter Anak Usia Dini
}

\author{
Narendradewi Kusumastuti \\ PG-PAUD STKIP Modern Ngawi \\ Narendradewi.k@gmail.com
}

\begin{abstract}
Abstrak
Penelitian ini bertujuan untuk mendeskripsikan tentang implementasi pilar-pilar karakter di TK ABA 2 Bojonegoro, meliputi: perencanaan pembelajaran, pelaksanaan pembelajaran, evaluasi, faktor pendukung dan penghambat. Penelitian ini menggunakan penelitian kualitatif jenis studi kasus. Subjek penelitian yaitu kepala sekolah, guru, dan anak. Pengumpulan data menggunakan observasi, wawancara, dan dokumentasi. Hasil penelitian yaitu: Perencanaan pembelajaran implementasi nilai-nilai karakter yaitu guru menyiapkan program semester, RPPM, dan RPPH, buku pilar karakter, media yang digunakan, pelaksanaan pembelajaran dalam mengimplementasikan 18 nilai-nilai karakter terintegrasi dalam setiap kegiatan pembelajaran, nilai-nilai karakter yang diimplementasikan adalah religius, jujur, toleransi, disiplin, kerja keras, kreatif, mandiri, demokratis, rasa ingin tahu, semangat kebangsaan, cinta tanah air, menghargai prestasi, bersahabat/ komunikatif, cinta damai, gemar membaca, peduli lingkungan, peduli sosial, dan tanggungjawab, metode pembelajaran implementasi pilar-pilar karakter yaitu metode keteladanan, metode pembiasaan, metode bercerita, metode karyawisata, dan metode bermain, evaluasi pembelajaran dalam implementasi 18 nilai karakter yaitu observasi, percakapan, unjuk kerja, dan catatan anekdot, faktor pendukung yaitu anak sangat antusias saat kegiatan pembelajaran karakter, media yang digunakan bervariatif, orangtua sangat mendukung adanya pendidikan karakter yang diterapkan di sekolah, faktor penghambat kurangnya waktu dalam pembelajaran nilai-nilai karakter.
\end{abstract}

Kata kunci: implementasi, pilar-pilar karakter, anak usia dini

\begin{abstract}
This study aimed to describe the implementation of character pillars in TK ABA 2 Bojonegoro, including: learning planning, learning implementation, evaluation, supporting and inhibiting factors. This research uses qualitative type of case study. Research subjects from principals, teacher, and children. Data collection using observation, interviews, and documentation. The results of the study are: Planning learning the implementation of character values, that the teacher prepares the semester program, RPPM, and RPPH, the character pillar books, media used, the implementation of learning in implementing 18 integrated character values in each learning activity, the character values implemented are religious, honest, tolerance, discipline, hard work, creative, independent, democratic, curiosity, passion nationality, patriotism, respect for achievement, friendly / communicative, peace loving, fond of reading, caring environment, social care, and responsibility, the method of learning in used in the education of early childhood character is the methods of precision, habituation methods, storytelling methods, field trip methods, and play methods, evaluation use is implementation of 18 character values, that is observation,
\end{abstract}

Implementasi Pilar-Pilar (Narendradewi) 333 
Jurnal Golden Age, Universitas Hamzanwadi

Vol. 04 No. 2, Desember 2020, Hal. 333-342

E-ISSN : 2549-7367

conversation, performance, and anecdot notes, the Supporting factors that children are very enthusiastic when character learning activities, the media used are varied, parents strongly support the existence of character education implemented in schools, inhibiting factors of lack of time in learning character values.

Keyword: implementation, character pillars, early childhood 


\section{PENDAHULUAN}

Pendidikan anak usia dini merupakan pendidikan sebelum memasuki jenjang pendidikan dasar (SD) yang memberikan perawatan dan pengasuhan kepada anak usia 0-6 tahun. Pendidikan anak usia dini membentuk dan mengoptimalkan perkembangan sikap, pengetahuan, karakter pada anak. Selain itu juga menitikberatkan pada enam aspek perkembangan yaitu moral dan agama, kognitif (daya pikir), bahasa (komunikasi), sosial emosional (emosi dan sikap), fisik motorik (motorik kasar dan halus), dan seni. Stimulasi dan rangsangan yang diberikan anak yang bertujuan membentuk anak menjadi pribadi berakhlak mulia (bermoral dan berkarakter), percaya diri, kreatif, kritis, mandiri dan bertanggungjawab (Elmanora et al., 2017; Ramdhani et al., 2019).

Anak dipandang sebagai makhluk yang unik dan berpotensi positif. Anak dipandang sebagai individu yang baru mengenal dunia, belum mengenal tata krama, sopan santun, aturan, norma, etika dan berbagai hal lainnya. Anak perlu dibimbing, diajarkan agar memahami keterampilan-keterampilan yang dibutuhkan untuk hidup bermasyarakat. sistem otak menghasilkan perilaku, saraf visual, saraf auditori, dan saraf motorik guna memproses informasi (materi pelajaran) secara simultan sehingga menghasilkan tindakan atau perilaku. Anak-anak Indonesia harus dibangun, dibina, disiapkan, dan dikembangkan sejak sedini mungkn baik fisik, mental, kepribadian, maupun moral agar kelak menjadi manusia yang bertakwa kepada Tuhan Yang Maha Esa, bertanggungjawab, menjadi insan pembangunan dan penerus cita-cita perjuangan bangsa dan negara (Suhirman, 2017; Turan \& Ulutas, 2016; Wijayanto \& Siradj, 2017).

Pendidikan untuk anak usia dini merupakan salah satu sekolah yang menerapkan pendidikan nilai-nilai karakter. Pembelajaran dilakukan dengan sentra dan menggunakan buku 9 pilar-pilar karakter. Pembelajaran pendidikan karakter sangat tepat diterapkan pada anak usia dini karena masa ini anak mengalami pertumbuhan dan perkembangan yang sangat pesat. Pengaruh negative yang belum dimiliki anak dari lingkungan akan membuat guru dan orangtua mudah untuk mendidik, mengarahkan, dan membimbing anak terutama dalam hal pendidikan karakter. Implementasi pendidikan pilar-pilar karakter diharapkan mampu memberikan/ menanamkan nilai-nilai kebaikan (moral dan karakter) agar anak memiliki karakter yang baik dan akan menjadi pembiasaan yang baik pula ketika anak dewasa.

karakter merupakan watak atau budi pekerti. Seseorang yang memiliki karakter kuat/ teguh yaitu seseorang yang tidak mau dikuasai oleh realitas yang ada. Sedangkan seseorang dengan karakter lemah adalah mereka yang mudah tunduk atau patuh pada kondisi yang ada. pendidikan karakter adalah pendidikan yang mengajarkan tabiat, moral, tingkah laku maupun kepribadian. Proses pembelajaran karakter yang dilakukan di lembaga pendidikan harus mengarahkan, mengembangkan, mendidik, dan menanamkan nilai-nilai kebaikan kepada anak dan diimplementasikan kehidupan 
sehari-hari dalam kehidupan anak usia dini. Pendidikan karakter merupakan bimbingan kepada anak agar mempunyai sikap dan tingkah laku yang baik sesuai dengan ajaran Agama dan norma-norma yang ada di masyarakat (Cahyaningrum et al., 2017; Ramdhani \& Yuliastri, 2018).

Metode implementasi pembelajaran karakter salah satu cara penyampaian materi kepada anak usia dini yang dilakukan dengan menyenangkan untuk mencapai kegiatan pembelajaran. Metode pembelajaran pendidikan karakter disesuaikan perkembangan anak usia dini, metode yang digunakan harus mengembangkan kemajuan anak usia dini. metode pembelajaran pendidikan karakter anak usia dini yaitu dengan menggunakan metode keteladanan, pembiasaan, bercerita, dan karyawisata (Amilda, 2017; Giri \& Supriatna, 2018).

Metode pembiasaan efektif dilakukan pembentukan karakter anak usia dini. Hal ini karena anak usia dini mempunyai ingatan kuat dan mudah diberikan stimulus sehingga mudah diatur dengan pembiasaan yang dilakukan sehari-hari. Metode pembiasaan erat kaitannya dengan metode keteladanan. Kebiasaan anak erat kaitannya dengan figur yang dicontoh. Pembiasaan adalah pengulangan, pembiasaan sangat efektif untuk melatih anak usia dini dalam kebiasaan-kebiasaan yang baik. Kegiatan yang dilakukan anak dalam metode pembiasaan misalnya berdoa sebelum makan, mengambil makanan dengan tangan kanan, mengucapkan terimakasih jika mendapatkan suatu kebaikan, memakai pakaian yang sopan, dan lain sebagainya.

Metode bercerita merupakan salah satu pemberian pengalaman belajar kepada anak dengan membawakan cerita baik secara lisan maupun tulisan. Cerita yang disampaikan harus menarik dan dapat mengundang perhatian anak. Isi cerita tentang kehidupan anak dan dekat dengan lingkungan anak. Cara ini dilakukan agar anak bisa memahami isi cerita mendengarkan dengan penuh perhatian dan dapat dengan mudah menangkap cerita. Dunia anak banyak dengan kegembiraan dan sukacita maka saat bercerita harus memberikan perasaan senang, gembira, lucu dan mengasyikkan. Metode bercerita merupakan sebagai upaya untuk mengoptimalkan perkembangan moral dan agama pada anak usia dini. menyebutkan bahwa cerita yang diberikan untuk anak usia 3-4 tahun maksimal 10 menit sedangkan anak usia 5-6 tahun maksimal 15 menit. Guru atau orangtua dapat mengambil cerita tentang Nabi atau cerita yang berasal dari nusantara misalnya Malin Kundang dan Timun Emas. Bercerita bisa dilakukan dengan lisan atau menggunakan media seperti, membaca buku cerita, membaca dari gambar, media boneka tangan, papan flanel, wayang dan lain-lain.

Metode karyawisata suatu metode pengajaran dengan cara mengamati makhluk hidup (manusia, hewan, tumbuhan dan benda-benda sekitarnya). Penggunaan metode karyawisata ini, anak akan belajar mendengar, merasakan, melihat, dan melakukan. Anak dapat mendengarkan suara di lingkungan sekitar (burung, air, tumbuhan, angin dan lain sebagainya). Selain itu. Anak juga mampu merasakan air yang dingin, matahari 
yang panas, semilir angin, dan lain-lain. Anak juga dapat melihat berbagai jenis tanaman, binatang, bentuk benda-benda disekitarnya, menyentuh pohon, daun, batu dan lainnya. Karyawisata dapat menumbuhkan minat, rasa ingin tahu anak terhadap sesuatu yang ada di lingkungan.. mengatakan bahwa metode karyawisata disebut dengan "field trip" artinya metode pengajaran yang dilakukan dengan cara mengajak anak ke luar kelas untuk memperhatikan kejadian yang berhubungan dengan kegiatan pembelajaran di kelas. Karyawisata penting untuk perkembangan anak karena meningkatkan minat, memunculkan kreativitas, memperoleh informasi, menambah pengetahuan baru, memperkaya program kegiatan belajar yang tidak bisa dihadirkan didalam kelas (Khaironi, 2017; Lee, 2016).

Metode bermain merupakan metode yang paling disenangi anak karena dunia anak adalah bermain. Kegiatan bermain adalah pendekatan dalam melakukan suatu pembelajaran di PAUD menggunakan berbagai macam strategi, metode, dan materi (bahan), serta media agar dapat dimengerti dan dipahami anak. Bermain merupakan kebutuhan mendasar bagi anak usia dini, dengan cara bermain anak merasakan kepuasan dalam berbagai hal seperti perkembangan motorik, kognitif, kreativitas, bahasa, emosi, sosial, dan sikap. Bermain juga membuat anak belajar bereksplorasi, menemukan, dan memanfaatkan benda yang ada disekitar lingkungan sehingga pembelajaran menjadi bermakna bagi anak. bermain merupakan suatu kegiatan atau aktivitas yang dilaksanakan untuk menimbulkan rasa bahagia tanpa mempertimbangkan hasil akhir, dilakukan sukarela, senang, gembira atas inisiatif sendiri, tidak ada paksaan atau tekanan. Sehingga bermain merupakan aktivitas langsung dan spontan, dimana anak berinteraksi dengan orang lain menggunakan rasa khayal (imajinatif), panca indera dan semua anggota tubuhnya(Elfiadi, 2016; Iswantiningtyas \& Wulansari, 2018).

\section{METODE PENELITIAN}

Penelitian ini untuk memperoleh gambaran tentang implementasi pendidikan karakter. Penelitian yang digunakan adalah penelitian kualitatif. Penelitian kualitatif menggunakan kata-kata sebagai data yang dikumpulkan dan dianalisis. Teknik pengumpulan data dilakukan dengan melakukan penelitian atau membentuk paradigma. penelitian kualitatif dimulai dengan anggapan, pengetahuan atau wawasan dunia, kemungkinan penggunaan teori, dan studi tentang masalah penelitian yang menganalisis individu atau kelompok yang dianggap berasal dari masalah sosial atau manusia (Cahyati \& Kusumah, 2020; Juanda, 2018).

Teknik pengumpulan data yang digunakan yaitu observasi, wawancara, dan studi dokumentasi. Metode studi dokumentasi berfungsi untuk mendapatkan informasi tentang pelaksanaan implementasi pendidikan karakter dan factor-faktor yang mendukung proses pembelajaran. Alat pengumpulan data dengan pedoman observasi, pedoman wawancara, dan dokumentasi dari lembaga sekolah. Aktivitas analisis data kualitatif dilakukan dengan cara interaktif dan berlangsung terus-menerus sampai 
selesai sehingga datanya sudah jenuh. Model analisis interaktif terdiri dari tiga hal utama yaitu reduksi data, penyajian data, dan penarikan kesimpulan. Pengumpulan data dapat sekaligus dilakukan analisis data, data yang diambil berupa sesuatu yang dilihat, didengar, dan diamati. Reduksi data merangkum, memilih pokok, fokus pada hal yang penting. Tahap reduksi data berlangsung terus menerus selama penelitian berlangsung. Tahap penyajian data bisa berupa bagan, uraian singkat, tabel, grafik dan lain-lain. Tahap penarikan kesimpulan merupakan kesimpulan awal yang didukung dengan bukti yang valid (Rahmat, 2009; Sugiono, 2010).

\section{HASIL PENELITIAN DAN PEMBAHASAN}

Perencanaan implementasi pendidikan karakter anak usia dini disusun secara beralur. Perencanaan pembelajaran pendidikan karakter anak usia dini menggunakan kurikulum 2013 (K13). Perencanaan pembelajaran program semester sudah menentukan indikator-indikator yang akan dicapai. Indikator-indikator yang ada pada program semester menjadi acuan dalam pembuatan Perencanaan Pelaksanaan Pembelajaran Mingguan (RPPM) dan Perencanaan Pelaksanaan Pembelajaran Harian (RPPH). Indikator-indikator di program semester diuraikan yang akan hendak dicapai selama seminggu berupa RPPM. RPPM berisi tentang tema, subtema, topik, pembelajaran sentra, dan pilar-pilar karakter. Setelah itu, guru membuat RPPH dan menguraikan dari indikator-indikator yang ada di RPPM. RPPH berisi tentang kegiatan pembelajaran selama satu hari, nilai karakter yang akan ditanamkan, dan metode yang digunakan saat pembelajaran. Hal tersebut sesuai dengan perencanaan pembelajaran Permendiknas nomor 58 tahun 2009 tentang standar isi, proses dan penilaian. Perencanaan pembelajaran meliputi perencanaan semester, RPPM, dan RPPH. Hal ini sejalan dengan bahwa Hakim \& Sobarna (2017:2) pengembangan kegiatan pembelajaran membutuhkan perencanaan seperti perencanaan mingguan dan harian.

Implementasi pembelajaran karakter anak usia dini menggunakan buku 9 pilar karakter dan K4 (Kebersihan, Kerapian, Kesehatan, dan Keamanan). 9 pilar-pilar karakter tersebut terdiri dari Pilar 1 (Cinta Tuhan dan Segenap Ciptaannya), Pilar 2 (Kemandirian, Disiplin, dan Tanggungjawab), Pilar 3 (Kejujuran, Amanah, dan Berkata Bijak), Pilar 4 (Hormat dan Santun), Pilar 5 (Dermawan, Suka Menolong, dan Kerjasama), Pilar 6 (Percaya Diri, Kreatif, dan Pantang Menyerah), Pilar 7 (Kepemimpinan dan Keadilan), Pilar 8 (Baik dan Rendah Hati), dan Pilar 9 (Toleransi, Kedamaian, dan Kesatuan). Pembelajaran karakter dilakukan di sekolah baik diluar kelas maupun didalam kelas. Hal ini sesuai dengan Berkowitz dan Bier (2006:4) mengatakan bahwa program pendidikan karakter yang efektif sering menargetkan pengembangan moral dan melaksanakan diskusi moral di ruang kelas.

Pelaksanaan pembelajaran dalam mengimplementasikan dan menanamkan 18 nilai-nilai karakter anak usia dini sudah terintegrasi dalam setiap kegiatan pembelajaran. Karakter religius ditunjukkan seperti setiap hari anak-anak melakukan shalat dhuhur berjamaah, hari jumat melakukan shalat dhuha, mengajak anak berdoa sebelum dan 
sesudah kegiatan. (Andriani, 2012; Inawati, 2017) Pendidikan karakter menjadi bagian proses membentuk akhlak anak. Karakter jujur dilakukan dengan pembelajaran jujur yang dilakukan anak-anak dengan bermain peran menjadi penjual dan pembeli. Anak bermain seolah-olah membeli barang dagangan dan menyerahkan sejumlah uang, jika uang tersebut sisa maka harus dikembalikan. Karakter toleransi seperti dalam kegiatan pembelajaran yang diterapkan untuk anak yaitu dengan saling menghargai dan menghormati jika berbeda pendapat yang berbeda dengan dirinya. Selain itu anak juga menghormati dan menghargai dengan perbedaan warna kulit, rambut, dan bentuk tubuh. Jika ada anak yang belum bisa menghargai perbedaan maka guru memberikan penjelasan, pemahaman kepada anak tersebut.

Karakter disiplin di tunjukkan kepada anak-anak anak usia dini dengan memakai seragam sesuai jadwal, mematuhi aturan misalnya datang ke sekolah sebelum pukul 07.30 dan pulang sekolah pukul 11.00. Kegiatan pembelajaran karakter disiplin lainnya anak meletakkan tas dan sepatu pada tempatnya, antri saat wudhlu, cuci tangan, dan mengambil makan siang. Kegiatan ini dilatih oleh guru setiap harinya dan dibiasakan terus menerus kepada anak. Apabila peraturan-peraturan sederhana ini dibiasakan akan menjadikan anak disiplin dalam melakukan segala aktivitasnya dan akan menjadi karakter dalam kehidupannya.

Karakter kerja keras dilakukan dengan mengerjakan tugas dari guru misalnya meronce, menggunting, membersihkan halaman, mengumpulkan daun kering dan dimasukkan ke tempat sampah. Guru memberikan motivasi kepada anak agar mampu menyelesaikan tugas dengan baik. Karakter kreatif dilakukan anak dengan bermain balok. Anak-anak dengan bebas bisa mengekspresikan kreatifitasnya dengan media yang disediakan, biasanya anak membuat istana, rumah, stasiun, masjid dan lain sebagainya. Kegiatan kreatif lainnya yang dilakukan anak yaitu dengan bermain dengan alam misalnya, bermain pasir, tanah liat, daun-daunan. Selain itu guru juga mengajak anak membuat mainan dari bahan bekas. Bahan bekas yang dipakai seperti ampas kelapa yang sudah tidak terpakai di campur dengan pewarna makanan kemudian dibuat tempal pada gambar yang ada. Bahan bekas lain seperti botol yakult dibuat boneka dan di gantung di depan kelas.

Karakter mandiri dilakukan dengan bimbingan guru kepada anak adalah makan sendiri tanpa bantuan oranglain. Kegiatan lainnya yaitu guru mengajak anak berkebun kemudian setelah selesai anak mencuci tangan dan kakinya sendiri dengan didampingi guru, jika kurang bersih guru meminta anak untuk membersihkannya lagi. Karakter demokratis dilakukan baik didalam pembelajaran maupun diluar pembelajaran. Kegiatan pembelajaran demokratis ini terlihat dari anak yang diberi kesempatan oleh guru untuk bertanya atau mengungkapkan pendapat dari pemikirannya, misalnya setelah guru becerita atau menyampaikan pembelajaran anak berpendapat atau bertanya tentang cerita tersebut.

Karakter rasa ingin tahu nampak pada rasa ingin tahu anak terlihat dari anak sering bertanya kepada guru baik tentang kegiatan pembelajaran di sekolah maupun 
kegiatan di luar sekolah. Kegiatan pembelajaran yang merangsang anak untuk bertanya misalnya saat guru memberikan kegiatan bermain sains dengan lilin. Anak sangat antusias dan bertanya kepada guru "waaahh bagus, bu kenapa lilinnya padam dan airnya masuk kedalam gelas?”, guru memberi penjelasan tentang sains yang diperagakan tersebut. Karakter semangat kebangsaan yang dilakukan seperti upacara bendera disetiap hari senin dan menyanyikan lagu-lagu kebangsaan. Karakter cinta tanah air di implementasikan yaitu menggunakan pakaian daerah saat hari kartini, mengenalkan pada anak tentang rumah adat, pakaian adat, dan lagu-lagu kebangsaan. Kegiatan lainnya yang dilaksanakan di luar sekolah adalah mengajak anak mengunjungi terminal dan naik bus mengelilingi kota. Kegiatan ini mengajarkan untuk bisa merawat fasilitas umum dan tidak merusaknya. Karakter menghargai prestasi yang ditanamkan pada anak yaitu menghargai hasil karya dari teman lain. Kegiatan yang dilakukan guru memberikan tugas buat anak untuk menggambar bebas kemudian menceritakannya di depan kelas. Karakter bersahabat/ komunikatif dilakukan anak dengan senang berkumpul, berbicara dengan teman. Nilai karakter lebih terlihat saat istirahat, semua anak berkumpul di halaman, kantin, atau arena outbond dengan bercanda dengan teman lainnya. Karakter cinta damai ditanamkan kepada anak dengan meminta izin apabila ingin meminjam barang ke teman, meminta tolong ketika membutuhkan bantuan dan meminta maaf apabila melakukan kesalahan. Kata maaf, tolong, dan meminta izin selalu dibiasakan oleh guru kepada anak-anak agar memiliki rasa cinta damai kepada siapa saja. Karakter gemar membaca yang dilakukan guru untuk anak-anak salah satunya dengan membacakan cerita bergambar maupun buku cerita anak. Selain itu di sekolah juga menyediakan perpustakaan kecil yang berisi macam-macam buku anak. Karakter peduli lingkungan diimplementasikan dengan berbagai kegiatan misalnya memberi makan binatang, menanam sayur, menyiram tanaman, mengganti pot yang rusak, memanen sayuran hasil dari kebun dan menjualnya. Peduli lingkungan lebih sering diimplementasikan karena sekolah ini berbasis alam. Karakter peduli sosial ditunjukan dengan membagikan sembako kepada orang yang lebih membutuhkan, mengundang anak yatim untuk berbuka puasa, menyisihkan uang saku setiap hari jumat untuk disumbangkan kepada fakir miskin. Karakter tanggungjawab dilakukan setiap harinya yaitu anak diberikan tugas dan harus diselesaikan, membereskan mainan dan mengembalikan ke tempatnya. Implementasi pembelajaran nilai-nilai karakter sesuai dengan Hakim \& Sobarna (2017:4) mengatakan bahwa pengkondisian pembelajaran dilakukan menyapa anak, berdoa sebelum belajar, upacara bendera, disiplin serta toleransi dan berjabat tangan.

Implementasi 18 nilai karakter tersebut di laksanakan di sekolah hal ini sesuai dengan (Kusumandari, 2013) mengatakan bahwa untuk memperkuat implementasi karakter ada 18 nilai bersumber agama, pancasila, budaya, dan tujuan pendidikan nasional yaitu beragama, jujur, toleransi, disiplin, kerjakers, kreatif, independen, demokratis, keingintahuan, semangat kebangsaan, cinta negara, penghargaan prestasi, 
ramah, cinta damai, suka membaca, peduli lingkungan, kepedulian sosial, tanggungjawab.

Metode implementasi 18 nilai karakter dilakukan anak setiap hari baik dari pagi sampai pulang sekolah. Metode dalam menanamkan karakter dengan menggunakan metode keteladanan yaitu berkata sopan, berpakaian rapi dan sopan, bersikap sabar, tidak mudah marah, dan bercerita dengan kisah para Nabi. Metode pembiasaan diterapkan kepada anak meliputi mengucapkan salam, berdoa sebelum dan sesudah melakukan aktivitas, selalu memakai jilbab tidak boleh di lepas, mengambil sesuatu dengan tangan kanan, berbagi dengan teman, mengembalikan mainan pada tempatnya. (setyaningrum, 2017) tauhid uluhiyah merupakan aspek pembiasaan tauhid, membaca doa, thoharoh, berlatih sholat, membaca thayyibah dan hafalan hadits. Metode bercerita yang diterapkan kepada anak dalam mengimplementasikan nilai karakter dengan anak mendengarkan cerita dari guru. Hari senin dan selasa guru bercerita dengan buku pilar karakter, hari rabu guru bercerita sesuai tema pilar karakter, dan hari kamis guru bercerita dengan boneka tangan. Setelah bercerita guru memberikan pertanyaan dari cerita yang disampaikan dan memberi kesempatan kepada anak yang mau menceritakannya kembali di depan kelas. Metode karyawisata yang dilakukan anak yaitu mengunjungi masjid-masjid, taman safari, pabrik tahu, pabrik gerabah dan lainnya. Metode karyawisata ini sangat disenangi oleh anak karena anak secara langsung belajar dengan lingkungan sekitar. Metode bermain yang diimplementasikan dalam nilai-nilai karakter kepada anak dengan cara mengajak anak bermain peran menjadi penjual dan pembeli, outbond, bermain estafet, dan lain-lain. Metode yang diterapkan implementasi nilai-nilai karakter anak usia dini sesuai dengan (Billah, 2016; Khaironi, 2018)yang menyatakan bahwa upaya mengoptimalisasi karakter, perkembangan moral dan nilai-nilai agama dilakukan dengan metode keteladanan, pembiasaan, bercerita, karyawisata, permainan, nasehat.

Evaluasi pembelajaran yang dilakukan dengan menilai anak setiap harinya. Evaluasi yang digunakan guru berupa observasi, percakapan, unjuk kerja, dan catatan anekdot. Observasi kepada anak dilakukan oleh guru selama proses pembelajaran berlangsung. Guru melihat sikap dan perilaku anak selama kegiatan pembelajaran. Evaluasi berupa percakapan dilakukan guru saat pembelajaran maupun setelah kegiatan pembelajaran. Percakapan guru dan anak berupa pertanyaan yang dilakukan kegiatan anak sehari-hari (perilaku baik dan buruk yang dilakukan) dan bagaimana tanggapan atau pendapat anak menjawab pertanyaan dari guru. Di samping itu guru juga memberikan penjelasan kepada anak hal baik yang harus dilakukan dan hal buruk yang tidak boleh dilakukan. Unjuk kerja dilakukan guru saat kegiatan pembelajaran berlangsung. Apakah anak mau melakukan perbuatan yang di contohkan guru apa tidak? misalnya ada plastik berserakan lalu dibaung di tempat sampah. Catatan anekdot dilakukan oleh guru apabila ada peristiwa penting saat kegiatan pembelajaran. Catatan anekdot ini di buat guru ketika anak sudah pulang dari sekolah. Evaluasi yang dilakukan guru juga berupa raport yang akan diserahkan kepada orangtua ketika akhir semester. 
Evaluasi yang dilakukan ini sesuai dengan Peraturan Menteri Pendidikan dan Kebudayaan Nomor 146 Tahun 2014 tentang kurikulum pendidikan anak usia dini dan pedoman penilaian menyebutkan bahwa "beberapa alat penilaian kompetensi sikap, pengetahuan, dan keterampilan termasuk penilaian formatif yaitu observasi, percakapan, unjuk kerja, penugasan, dan catatan anekdot”. Dubiel (2014:36) penilaian formatif adalah menterjemahkan informasi secara langsung bagaimana guru menanggapi, berinteraksi, menyiapkan pembelajaran dan perkembangan anak-anak.

Faktor pendukung dalam mengimplementasikan nilai-nilai karakter pada anak usia dini yaitu anak merasa senang dan sangat antusias saat kegiatan pembelajaran karakter, media yang digunakan saat pembelajaran mengimplementasikan nilai-nilai karakter sudah banyak dan bervariatif, orangtua sangat mendukung dengan adanya buku 9 pilar karakter yang diterapkan di sekolah. Hal ini sesuai (Castro, 2014; Nuraeni et al., 2019; Tanto et al., 2019)yang menyebutkan bahwa keluarga merupakan unsur paling penting dalam kehidupan anak, di keluarga anak mendapatkan pendidikan moral, karakter, emosional, dan fisik untuk membantu perkembangan anak menjadi optimal. Faktor penghambat dalam mengimplementasi nilai-nilai karakter pada anak usia dini yaitu kurangnya waktu dalam pembelajaran nilai-nilai karakter sehingga kurang maksimal. Pembelajaran pilar-pilar karakter di lakukan setiap hari hanya 15 menit saja, karena saat kegiatan jurnal pagi anak diharuskan mengaji, hafalan hadist, dan calistung. Sehingga porsi pembelajaran pilar-pilar karakter masih sangat kurang.

\section{KESIMPULAN}

Nilai-nilai karakter yang diimplementasikan yaitu religius, jujur, toleransi, disiplin, kerja keras, kreatif, mandiri, demokratis, rasa ingin tahu, semangat kebangsaan, cinta tanah air, menghargai prestasi, bersahabat/ komunikatif, cinta damai, gemar membaca, peduli lingkungan, peduli sosial, serta tanggungjawab. Metode pembelajaran yang digunakan pembelajaran pendidikan karakter untuk anak usia dini yaitu metode keteladanan, metode pembiasaan, metode bercerita, metode karyawisata, dan metode bermain. Perencanaan pembelajaran nilai-nilai karakter menyiapkan program semester, RPPM, dan RPPH. Pelaksanaan pembelajaran dalam menanamkan 18 nilai-nilai karakter yang terintegrasi dalam setiap kegiatan pembelajaran, Evaluasi pembelajaran dalam menanamkan 18 nilai karakter yaitu observasi, percakapan, unjuk kerja, dan catatan anekdot. Guru juga secara langsung juga menindak perilaku yang tidak sesuai dengan nilai-nilai yang berlaku. Faktor pendukung dalam menanamkan nilai-nilai karakter adalah anak sangat antusias saat kegiatan pembelajaran karakter, media yang digunakan saat pembelajaran nilai-nilai karakter bervariatif, orangtua mendukung pendidikan karakter dan adanya buku 9 pilar karakter yang diterapkan di sekolah. Faktor penghambat kegiatan pembelajaran mengimplementasi nilai-nilai karakter yaitu kurangnya waktu dalam pembelajaran nilai-nilai karakter sehingga kurang maksimal.

\section{DAFTAR PUSTAKA}


Amilda, A. (2017). Pembentukan Karakter Anak Usia Dini Melalui Pembiasaan. Raudhatul Athfal: Jurnal Pendidikan Islam Anak Usia Dini, 1(2), 11-18. https://doi.org/10.19109/ra.v1i2.2684

Andriani, T. (2012). Permainan Tradisional Dalam Membentuk Karakter Anak Usia Dini. Jurnal Sosial Budaya, 9(1), 121-136.

Billah, A. (2016). Pendidikan Karakter Untuk Anak Usia Dini dalam Perspektif Islam dan Implementasinya dalam Materi Sains. ATTARBIYAH: Journal of Islamic Culture and Education, 1(2), 243-272. https://doi.org/10.18326/attarbiyah.v1i2.

Cahyaningrum, E. S., Sudaryanti, S., \& Purwanto, N. A. (2017). Pengembangan NilaiNilai Karakter Anak Usia Dini Melalui Pembiasaan Dan Keteladanan. Jurnal Pendidikan Anak, 6(2), 203-213. https://doi.org/10.21831/jpa.v6i2.17707

Cahyati, N., \& Kusumah, R. (2020). Peran Orang Tua Dalam Menerapkan Pembelajaran Di Rumah Saat Pandemi Covid 19. Jurnal Golden Age, Universitas Hamzanwadi, 04(1), 152-159.

Castro, D. C. (2014). The development and early care and education of dual language learners: Examining the state of knowledge. Early Childhood Research Quarterly, 29(4), 693-698. https://doi.org/10.1016/j.ecresq.2014.08.003

Elfiadi. (2016). Bermain Dan Permainan Bagi Anak Usia Dini. Jurnal Itqan, VII(1), 5160 .

Elmanora, E., Hastuti, D., \& Muflikhati, I. (2017). Lingkungan Keluarga sebagai Sumber Stimulasi Utama untuk Perkembangan Kognitif Anak Usia Prasekolah. Jurnal Ilmu Keluarga Dan Konsumen, 10(2), 143-156. https://doi.org/10.24156/jikk.2017.10.2.143

Giri, R. A., \& Supriatna, N. (2018). TOLERANCE AS A CHARACTER EDUCATION IN SOCIAL STUDIES LEARNING FOR 21 ST CENTURY. 183-191.

Inawati, A. (2017). Strategi Pengembangan Moral dan Nilai Agama Untuk Anak Usia Dini. Jurnal Pendidikan Anak, 3(1), 51-64.

Iswantiningtyas, V., \& Wulansari, W. (2018). Pentingnya Penilaian Pendidikan Karakter Anak Usia Dini. Proceedings of the ICECRS, 1(3), 197-204. https://doi.org/10.21070/picecrs.v1i3.1396

Juanda. (2018). Revitalisasi Nilai Dalam Dongeng Sebagai Wahana Pembentukan Karakter Anak Usia Dini. Jurnal Pustaka Budaya, 5(2), 11-18. https://doi.org/10.19109/ra.v1i2.2684

Khaironi, M. (2017). Penanaman sikap beragama dan moral anak usia dini di TKIT Salman Al Farisi 2. JPPM (Jurnal Pendidikan Dan Pemberdayaan Masyarakat), 4(2), 166-179. https://doi.org/10.21831/jppm.v4i2.9787

Khaironi, M. (2018). Perkembangan anak usia dini. Jurnal Golden Age Hamzanwadi University, 3(1), 1-12.

Lee, A. (2016). Implementing character education program through music and integrated activities in early childhood settings in Taiwan. International Journal of Music Education, 34(3), 340-351. https://doi.org/10.1177/0255761414563195 
Nilai, M., Anak, K., \& Dini, U. (2018). E-issn : 2549-7367. 3(1), 44-58.

Nuraeni, L., Andrisyah, A., \& Nurunnisa, R. (2019). Efektivitas Program Sekolah Ramah Anak dalam Meningkatkan Karakter Anak Usia Dini. Jurnal Obsesi : Jurnal Pendidikan Anak Usia Dini, 4(1), 20. https://doi.org/10.31004/obsesi.v4i1.204

Rahmat, P. S. (2009). Penelitian Kualitatif. In Journal Equilibrium: Vol. 5 No. 9 (pp. 18). yusuf.staff.ub.ac.id/files/2012/11/Jurnal-Penelitian-Kualitatif.pdf

Ramdhani, S., Yuliastri, N. A., Sari, S. D., \& Hasriah, S. (2019). Penanaman Nilai-Nilai Karakter melalui Kegiatan Storytelling dengan Menggunakan Cerita Rakyat Sasak pada Anak Usia Dini. Jurnal Obsesi : Jurnal Pendidikan Anak Usia Dini, 3(1), 153. https://doi.org/10.31004/obsesi.v3i1.108

Sugiono. (2010). Metode Penelitian Pendidikan; Pendekatan Kuantitatif, Kualitatif dan $R \& D$ (cetakan ke). Alfabeta, CV.

Suhirman, S. (2017). Cerita Tradisional Sasak Lombok Sebagai Sarana Transmisi Budaya Untuk Membentuk Karakter Anak Sejak Usia Dini. Jurnal Golden Age, 1(01), 48. https://doi.org/10.29408/goldenage.v1i01.481

Tanto, O. D., Hapidin, H., \& Supena, A. (2019). Penanaman Karakter Anak Usia Dini dalam Kesenian Tradisional Tatah Sungging. Jurnal Obsesi : Jurnal Pendidikan Anak Usia Dini, 3(2), 337. https://doi.org/10.31004/obsesi.v3i2.192

Turan, F., \& Ulutas, I. (2016). Using storybooks as a character education tools. Journal of Education and Practice, 7(15), 169-176.

Wijayanto, P. W., \& Siradj, Y. (2017). The Educational Game "Indonesian Tribes" for the Kindergarten Students. IJPTE: International Journal of Pedagogy and Teacher Education, 1(1), 27-36. https://doi.org/10.20961/ijpte.v1i1.8456 